\title{
Effects of different banana crop residue hays on ensiling BRS capiaçu grass on fermentation profile, aerobic stability and nutritional value of silage
}

\section{Efeitos de diferentes fenos de resíduo da bananicultura na ensilagem do capim-BRS capiaçu sobre o perfil de fermentativo, estabilidade aeróbia e valor nutricional da silagem}

Ariadne Freitas Silva1; Flávio Pinto Monção²*; João Paulo Sampaio Rigueira ${ }^{3}$; Vicente Ribeiro Rocha Júnior ${ }^{3}$; Amanda Maria Silva Alencar ${ }^{1}$; Cinara da Cunha Siqueira Carvalho ${ }^{3}$; Carlos Juliano Brant Albuquerque ${ }^{4}$; Fredson Vieira e Silva3; Renam Lucas Miorin ${ }^{5}$; Eleuza Clarete Junqueira de Sales ${ }^{3}$

\section{Highlights}

Ensiling banana crop residue represents a practical strategy.

Banana crop residue has great potential to be used in the ensiling process.

The BRS capiaçu grass silage combined with banana peel decreases dry matter losses.

The BRS capiaçu grass silage combined with pseudostem hay improves digestibility.

\section{Abstract}

The objective of this study was to evaluate the BRS capiaçu grass silage combined with different hays of banana crop residue on fermentation profile, aerobic stability and nutritional value. The treatments consisted of elephant grass cv. BRS capiaçu (Pennisetum purpureum Schum.) ensiled with $37.44 \%$ banana peel hay, $36.06 \%$ banana pseudostem hay and $37.00 \%$ banana leaf hay, on a dry matter (DM) basis and control silage (no additive). The experimental design used was completely randomized, with five treatments

1 Students of Animal Science Master's Course, Universidade Estadual de Montes Claros, UNIMONTES, Janaúba, MG, Brazil. E-mail: ariadnefreitassilva@yahoo.com.br; amandaalencar604@gmail.com

2 Prof. and Researcher PNPD/Capes, Postgraduate Program in Animal Science (Master), UNIMONTES, Janaúba, MG, Brazil. E-mail: moncaomoncao@yahoo.com.br

3 Profs. Drs., Postgraduate Program in Animal Science (Master), UNIMONTES, Janaúba, MG, Brazil. E-mail: joao. rigueira@unimontes.br; vicente.rocha@unimontes.br; cinara.carvalho@unimontes.br; fredson.silva@unimontes.br; eleusa.sales@unimontes.br

${ }^{4}$ Prof. Dr., Postgraduate Program in Animal Science (Master), Universidade Federal de Minas Gerais, UFMG, Montes Claros, MG, Brazil. E-mail: carlosjuliano@ufmg.br

5 Prof. EBTT, Dr., Instituto Federal de Mato Grosso, IFMT, Guarantã do Norte, MT, Brazil. E-mail: renan.miorin@gta.ifmt. edu.br

* Author for correspondence

Received: Apr. 05, 2021 - Approved: Aug. 30, 2021 
and five replicates. Forage was collected when it reached 3.5 meters in height ( 90 days). Experimental PVC silos of known weight, $50 \mathrm{~cm}$ long, $10 \mathrm{~cm}$ diameter, were used for silage making. For all treatments, silage aerobic stability breakdown started after 64 hours exposure to air. The BRS capiaçu grass control silage or silage combined with pseudostem hay (mean of $73.15 \mathrm{~kg} \mathrm{t} \mathrm{GM}^{-1}$ ) presented effluent losses $40.46 \%$ higher than those observed for BRS capiaçu grass silage + banana leaf hay and $69.17 \%$ in relation the BRS capiaçu grass silage + banana peel hay. The inclusion of banana crop residue (hay) when ensiling BRS capiaçu grass decreased $13.93 \%$ gas losses compared to the control silage (mean of $3.11 \%$ DM). Higher values of total digestible nutrients, metabolizable energy and digestible energy content was found in BRS capiaçu grass silage + with banana peel hay. The greater in vitro dry matter digestibility and in vitro neutral detergent fiber digestibility was observed for BRS capiaçu grass silage combined with pseudostem hay. The inclusion of $37.44 \%$ banana peel hay improves the fermentation profile and aerobic stability of BRS capiaçu grass silage.

Key words: pH. Effluent losses. Musa spp. Elephant grass. Digestibility. Residues.

\section{Resumo}

Ojetivou-se por meio desta pesquisa avaliar a silagem de capim-BRS capiaçu associada com diferentes fenos de resíduos da cultura da banana sobre o perfil fermentativo, estabilidade aeróbia e valor nutricional. Os tratamentos consistiram de capim-elefante cv. BRS capiaçu (Pennisetum purpureum Schum.) ensilado com $37,44 \%$ de feno de casca de banana, $36,06 \%$ de feno de pseudocaule de banana e $37,00 \%$ de feno de folha de bananeira, à base da matéria seca (MS), e a silagem controle (sem aditivo). 0 delineamento experimental utilizado foi inteiramente casualizado com cinco tratamentos e cinco repetições. A forragem foi coletada quando atingiu 3,5 metros de altura (90 dias). Para a produção da silagem, foram utilizados silos experimentais de PVC de peso conhecido, com $50 \mathrm{~cm}$ de comprimento e $10 \mathrm{~cm}$ de diâmetro. Para todos os tratamentos, a quebra da estabilidade aeróbia da silagem iniciou a partir de 64 horas de exposição ao ar. A silagem de BRS capiaçu controle ou associada ao feno de pseudocaule (média de 73,15 $\mathrm{kg} \mathrm{t} \mathrm{MN}^{-1}$ ) apresentaram perdas de efluentes $40,46 \%$ maiores do que as observadas para a silagem de BRS capiaçu associada ao feno de folha de bananeira e 69,17\% em relação à silagem de BRS capiaçu associada à casca de banana. A inclusão dos resíduos da cultura da banana (feno) na ensilagem do capim- BRS capiaçu diminuiu 13,93\% as perdas por gases em comparação com a silagem controle (média de 3,11\% da matéria seca - MS). Maiores teores de nutrientes totais digestíveis, energia metabolizável e energia digestível foram verificadas na silagem de BRS capiaçu associada à casca de banana. A maior digestibilidade in vitro da matéria seca e da fibra em detergente neutro foi verificada na silagem de BRS capiaçu associada com feno de pseudocaule. A inclusão de $37,44 \%$ de feno de casca de banana melhora o perfil fermentativo e a estabilidade aeróbia da silagem de capim- BRS capiaçu.

Palavras-chave: pH. Perdas de efluentes. Musa spp. Capim-elefante. Digestibilidade. Resíduos. 


\section{Introduction}

Elephant grass (Pennisetum purpureum Schum.) is a forage species used mainly as weeding (fresh forage), being source of roughage supplementation for animals in periods of low forage availability (Monção et al., 2019, 2020a,b; Jesus et al., 2021). To facilitate its management, silage becomes a viable alternative, especially when using high potential forage for production of mass. Among the elephant grass cultivars, stands out the BRS capiaçu recently released by Embrapa (Pereira et al., 2017) with differential of high yield potential (72 tons dry matter DM) and good nutritional value (crude protein of $94.2 \mathrm{~g} \mathrm{~kg}^{-1}$ DM and DM digestibility of $564 \mathrm{~g}$ $\mathrm{kg}^{-1} \mathrm{DM}$ ) as silage (Silva et al., 2019; Monção et al., 2019, 2020a,b; Ribas et al., 2021). However, the dry matter content in the recommended maturity at harvest (90-120 regrowth days; 3.5-4.5 meters high) for ensiling is less than 20\% (Pereira et al., 2017; Monção et al., 2019, 2020a), which may compromise the fermentation process in addition to presenting high effluent losses. Thus, it is necessary the wilting (Ribas et al., 2021) or the inclusion of moisture sequestering additives with the purpose of interfering with the fermentative dynamics and nutritional value (Muck et al., 2018; Silva et al., 2019; Paula et al., 2020).

Banana (Musa spp.) crop is an important activity in several regions of Brazil and worldwide, being generated residue as peel, leaves and pseudostem, which when dehydrated (hay) can be used as moisture absorbing additives in silage of tropical grasses, reducing fermentation losses (Brant et al., 2017; Rabelo et al., 2020; Rigueira et al., 2020, 2021). For each ton of banana harvested, approximately 4 tons of residue is generated, including peel, leaves, pseudostem and bunch stalk (Rabelo et al., 2020; Rigueira et al., 2021). About $75 \%$ of these residues are composed of banana pseudostem, which makes it an important alternative for use as silage because these wastes are discarded into the environment. In banana crops, these wastes can store pests and diseases for banana plantations. However, there are no studies in the literature regarding the use (inclusion) of banana residues in silage of BRS capiaçu grass on fermentation profile and nutritional value. Some studies highlighted the potential of banana crop residue when used in the diet for lactating cows (Rabelo et al., 2020) and dairy heifers (Rigueira et al., 2021). We hypothesized that the banana crop residue reduces DM losses and improve the nutritional value of BRS capiaçu grass silage.

Based on the above, the aim of this study was to evaluate the BRS capiaçu grass silage combined with different hays of banana crop residue on fermentation profile, aerobic stability and nutritional value.

\section{Material and Methods}

All animal care and handling procedures were approved by the Ethics committee on animal use of the State University of Montes Claros (Unimontes), Brazil (protocol CEBEAUnimontes 175/2018).

The experiment was conducted in the Animal Science sector of the State University of Montes Claros, Janaúba Campus (geographical coordinates: $15^{\circ} 52^{\prime} 38^{\prime \prime} \mathrm{S}$, $\left.43^{\circ} 20^{\prime} 05^{\prime \prime} \mathrm{W}\right)$. The climate of the region, according to the Köppen-Geiger classification, is $A w$, with summer rains and well-defined periods of drought in the winter. The average 
annual rainfall is $800 \mathrm{~mm}$, with an average annual temperature of $24^{\circ} \mathrm{C}$. The climate is tropical mesothermal, due to the altitude, sub-humid and semi-arid, with irregular rains, causing long periods of drought.

The treatments consisted of elephant grass cv. BRS capiaçu (Pennisetum purpureum Schum.) ensiled with $37.44 \%$ banana peel hay, $36.06 \%$ banana pseudostem hay and $37.00 \%$ banana leaf hay, on a dry matter basis and control silage (BRS capiaçu grass silage without additive). The inclusion of banana crop residue was defined according to Brant et al. (2017). The chemical composition of BRS capiaçu grass and banana crop residue are listed in Table 1.

Table 1

Chemical composition of the BRS capiaçu grass and banana crop residue, $\mathbf{g ~ k g}^{-1}$ dry matter.

\begin{tabular}{|ccccc|}
\hline Item & BRS capiaçu grass $^{1}$ & Banana peel hay & Pseudostem hay & Leaf hay \\
\hline Dry matter & 175.0 & 942.5 & 888.3 & 925.0 \\
\hline Ash & 97.5 & 141.4 & 170.6 & 115.3 \\
\hline Crude protein & 74.4 & 119.1 & 47.0 & 100.0 \\
Ether extract & 16.0 & 75.8 & 96.0 & 64.0 \\
\hline Neutral detergent fiber & 671.0 & 501.4 & 600.0 & 660.0 \\
\hline Acid detergent fiber & 462.0 & 407.2 & 460.0 & 387.0 \\
\hline
\end{tabular}

DM - dry matter; ${ }^{1} 90$ days (Monção et al., 2019, 2020a).

Forage was planted at UNIMONTES Experimental Farm on red-yellow eutrophic soil with clay texture and the following chemical characteristics: $\mathrm{pH}$ in $\mathrm{CaCl}_{2}, 6.3, \mathrm{P}$ (Mehlich): $21.2 \mathrm{mg} \mathrm{dm}^{-3} ; \mathrm{K}$ (Mehlich): $110 \mathrm{mmolc} \mathrm{dm}^{-3}$; $\mathrm{Ca}^{2+}\left(\mathrm{KCl} 1 \mathrm{~mol} \mathrm{~L}^{-1}\right): 3.9 \mathrm{cmolc} \mathrm{dm}^{-3} ; \mathrm{Mg}^{2+}(\mathrm{KCl} 1$ mol L-1 $): 1.1 \mathrm{cmolc} \mathrm{dm}^{-3} ; \mathrm{Al}^{3+}\left(\mathrm{KCl} 1 \mathrm{~mol} \mathrm{~L}^{-1}\right): 0.0$ cmolc dm $\mathrm{dm}^{-3}: \mathrm{H}+\mathrm{Al}$ (calcium acetate $0.5 \mathrm{~mol} \mathrm{~L}^{-1}$ ): $1.2 \mathrm{cmolc} \mathrm{dm}^{-3}$ : sum of bases $5.5 \mathrm{cmolc} \mathrm{dm}^{-3}$;

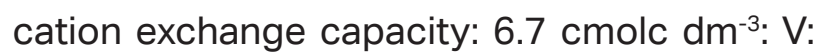
$82.00 \%$.

The forage used in this experiment was collected from pre-selected areas when it reached 3.5 meters high, 90 d; Monção et al. (2019, 2020a). After uniform harvest of forage, two tons bovine manure $(\mathrm{pH}-8.4 ; 217$ $\mathrm{g}$ moisture, $488 \mathrm{~g}$ dry matter, $11 \mathrm{~g} \mathrm{~kg}^{-1}$ nitrogen and $13 \mathrm{~g} \mathrm{~kg}^{-1}$ phosphorus) was applied per hectare.
Grass was manually harvested and later crushedina crusher-choppermachinecoupled to an electric motor; knives in the machine were set to grind the forage to a particle size of $2 \mathrm{~cm}$. Peel, leaves and pseudostem of banana were acquired at UNIMONTES Experimental Farm and shredded/chopped in a forage harvester coupled to the tractor (JF, $40 \mathrm{P}$, Itapura, São Paulo, Brasil) adjusting particle size to $2 \mathrm{~cm}$. These residues were spread on plastic canvas and made a $10 \mathrm{~cm}$ high layer and left to dry in the sun for 120 hours. Forage was harvested from five hills, and the additive was added in the respective proportions (10\% natural matter or $37.44,36.06$ and $37.00 \%$ on a dry matter basis) and homogenized before ensiling.

For silage, Polyvinylchloride (PVC) experimental silos of known weight, $50 \mathrm{~cm}$ 
long, $10 \mathrm{~cm}$ diameter were used. The bottom of the silos contained $10 \mathrm{~cm}$ dry sand $(400$ g), which was separated from the forage to quantify the effluent produced. After complete homogenization of the forage, the resulting material was deposited in the silos and compacted with a wooden plunger. For each treatment, silage density was quantified (550 $\mathrm{kg}$ natural matter $\mathrm{m}-3$ ) as recommended by Brüning, Gerlach, Weiß, and Südekum (2017). After filling, silos were closed with PVC caps equipped with Bunsen valves, sealed with adhesive tape and weighed. Silos were stored at room temperature and opened 60 days after sealing.

DM losses from silages as gases and effluents were quantified by weight difference of ensiled mass according to Jobim, Nussio, Reis and Schmidt (2007). For effluent loss, equation 1 was used.

$E=(P a b-P e n) /(G M f e) \times 1000 \quad$ (Equation 1)

where:

$\mathrm{E}$ : effluent losses ( $\mathrm{kg} \mathrm{ton}^{-1}$ green mass); Pab: weight of the set (bucket + cap + wet sand + foam) upon opening $(\mathrm{kg})$; Pen: weight of the set (bucket + cap + dry sand + foam) in the silage (kg); GMfe: silage green forage mass (kg).

DM losses as gases was calculated by the difference between the gross weight of the initial and final ensiled dry matter, in relation to the amount of ensiled DM, subtracting the weight of the silo and dry sand set, according to the equation (2):G $=\left[(P C e n-P e n)^{*} D M e n\right]-$ [(PCab-Pen)*DMab] x 100 [(PCen - Pen $)^{\star}$ DMen] (Equation 2)

Where:

G: gas losses (\% DM); PCen: weight of the full bucket upon sealing (kg); Pen: weight of the set (bucket + cap + dry sand + foam) in the silage (kg); DMen: forage dry matter content in silage; PCab: weight of full bucket upon opening (kg); DMab: forage dry matter content upon opening.

Aerobic stability was determined by placing a silage sample (approximately $3 \mathrm{~kg}$ ) from each silo in another silo and keeping it at room temperature $\left(24.5-25.5{ }^{\circ} \mathrm{C}\right)$. Silage temperature was measured every hour using a data logger placed at the center of the mass for six days. Room temperature was also measured every hour by a data collector placed near the silos. The $\mathrm{pH}$ was also measured. The determination of $\mathrm{pH}$ was obtained by silage extract. The $\mathrm{pH}$ was measured with a potentiometer (Ak 90, Akso Measuring Instruments, São Leopoldo, RS, Brasil). Aerobic stability was defined as the number of hours the silage temperature remained stable before increasing by more than $2{ }^{\circ} \mathrm{C}$ above ambient temperature.

Ammonia nitrogen (N-NH3) was measured in the silage extract (silage juice), obtained with a hydraulic press $\left(\right.$ Tecnal $^{\circledR}$, Piracicaba, SP, Brazil), according to Noel and Hambleton (1976).

A portion of silages was pre-dried in a forced air oven at $55^{\circ} \mathrm{C}$. Subsequently, all samples were ground in a knife mill with a $1 \mathrm{~mm}$ mesh sieve for laboratory analysis. Part of the samples were ground in a $2 \mathrm{~mm}$ mesh sieve for in vitro and in situ digestibility analysis. Samples were analyzed for dry matter content (INCT-CA G-001/1 and G-003/1), crude protein (INCT-CA N-001/1), ether extract (INCT-CA G-005/1), and ash (INCT-CA M-001/1), neutral detergent fiber (NDF; INCT-CA F-002/1) and acid detergent fiber (ADF; INCT-CA F-003/1), indigestible neutral detergent fiber (iNDF) 
(INCT-CA F-008/1), lignin (INCT-CA F-005/1) and non-fiber carbohydrates, according to Detmann et al. (2012). The content of total digestible nutrients (TDN) was estimated according to National Research Council [NRC] (2001). The contents of neutral detergent insoluble nitrogen (NDIN) and acid detergent insoluble nitrogen (ADIN) were determined according to Detmann et al. (2012), and the levels of neutral detergent insoluble protein (NDIP) and acid detergent insoluble protein (ADIP) were obtained by multiplying the NDIN and ADIN by 6.25 , respectively.

The in vitro digestibility of dry matter and neutral detergent fiber was determined according to the methodology described by Tilley and Terry (1963) adapted by Detmann et al. (2012), using the in vitro incubator of Tecnal ${ }^{\circledR}$ (TE-150), with modification of the bag material used $(7.0 \times 7.0 \mathrm{~cm})$, made with non-woven fabric bags $\left(100 \mathrm{~g} \mathrm{~m}^{-2}\right)$. The method used for in vitro digestibility simulates a ruminal digestion for 48 hours, followed by a digestion with pepsin and chlorhydric acid $(\mathrm{pH})$ for additional 48 hours.

The in situ incubation experiment was performed according to the methodology described by Ørskov \& McDonald (1979). Two cannulated crossbred steers, with an average body weight of $480 \pm 30 \mathrm{~kg}$ and mean age of 8 years, were adapted for 14 days to the diet containing $4 \mathrm{~kg}$ concentrate (25\% CP and $65 \%$ TDN), divided into two meals, morning and afternoon, in addition to the provision of roughage based on BRS capiaçu grass silage and hay of banana residue (60\% BRS capiaçu grass silage and $40 \%$ hay of banana residue). The in situ degradability technique was carried out in $7.5 \times 15 \mathrm{~cm}$ non-woven fabric bags (100 weight) with approximate porosity of $60 \mu \mathrm{m}$, according to Valente et al. (2011); the number of samples was determined from the ratio of $20 \mathrm{mg} \mathrm{DM} \mathrm{cm}^{-1}$ bag surface area.

Bags containing the samples were placed in filo bags of $20 \times 30 \mathrm{~cm}$, along with 100 grams lead. Bags were tied with nylon thread, leaving a length of $1 \mathrm{~m}$ so that the bags could move freely in the solid and liquid phases of the rumen. Bags were then deposited in the region of the ventral sac of the rumen with the tip of the nylon thread remaining attached to the cannula for $0,3,6,12,24,48,72,96$, and $120 \mathrm{~h}$ in reverse order, that is, starting with the duration of $120 \mathrm{~h}$. Bags related to time zero were not incubated in the rumen, however were washed in running water, similar to incubated bags. Subsequently, samples were placed in an oven at $55^{\circ} \mathrm{C}$ for $72 \mathrm{~h}$, and then cooled in a desiccator and weighed.

Residues remaining in non-woven fabric bags collected from the rumen were analyzed for DM, and NDF content. The percentage of degradation was calculated by the proportion of feed remaining in the bags after ruminal incubation.

Data obtained were fit to a non-linear regression by the Gauss-Newton method, in the SAS software (Statistical Analysis System Institute [SAS Institute], 2008), according to the equation proposed by Ørskov and McDonald (1979): $Y=a+b\left(1-e^{-c t}\right)$, where: $Y$ $=$ accumulated degradation of the nutrient analyzed after time $\mathrm{t}$; $\mathrm{a}=$ degradation curve intercept when $\mathrm{t}=0$, which corresponds to the water soluble fraction of the analyzed nutrient; $b=$ degradation potential of the water insoluble fraction of the analyzed nutrient; $a+b=$ potential degradation of the nutrient analyzed when time is not a limiting factor; $\mathrm{c}=$ degradation rate by fermentative action of $b ; t$ = incubation time. 
After calculating, the coefficients $a, b$ and c were applied to the equation proposed by Ørskov and Mcdonald (1979): ED = a + (bxc/c + k), where: ED = effective rumen degradability of the nutrient analyzed; $k$ = feed rate of passage. Rumen particle passage rates estimated at 2, 5 and $8 \% / h$, as suggested by Agricultural and Food Research Council [AFRC] (1993), were assumed. The disappearance value found at time zero ("a") was used to estimate the colonization time (CT) for DM, and NDF, according to Goes et al. (2017), where the parameters "a", "b", and "c" were evaluated by the Gaus-Newton algorithm: CT = [-In(a'-ab)/c].

NDF degradability was estimated using the model proposed by Mertens and Loften (1980): $R t=B \times e^{-c t}+I$, where $R=$ fraction degraded at time $\mathrm{t} ; \mathrm{B}=$ potentially digestible insoluble fraction and $\mathrm{I}=$ indigestible fraction. After adjusting the NDF degradability equation, fractions were standardized using the equations: $\mathrm{Bp}=\mathrm{B} /(\mathrm{B}+\mathrm{I}) \times 100 ; \mathrm{I}_{\mathrm{p}}=\mathrm{I} /(\mathrm{B}+$ I) $\times 100$, where: $\mathrm{Bp}=$ standardized potentially digestible fraction (\%); Ip = standardized indigestible fraction (\%); $\mathrm{B}=$ potentially digestible insoluble fraction and $\mathrm{I}=$ indigestible fraction. The effective NDF degradability was calculated according to the model: $E D=$ $\mathrm{Bp} \times \mathrm{c} /(\mathrm{c}+\mathrm{k})$, where $\mathrm{Bp}$ is the standardized potentially digestible fraction (\%).

The experimental design used for the fermentation profile and nutritional value was the completely randomized, with five treatments and five replicates. We adopted the model:

Yij $=\mu+T i+\varepsilon i j$, where $Y i j=$ observation of the effect of treatment $i$ in the replication $j$; $\mu=$ overall mean; $\mathrm{Ti}=$ effect of the treatment $\mathrm{i}$ applied to the plot, with $\mathrm{i}=1,2,3,4$ and 5; عijk = random error associated with each observation. The means were compared by the Scott Knott test.

For variables related to aerobic stability, we used a split plot completely randomized design, with five treatments (parcels), five times of exposure to the air (subplots), and five replicates. The mathematical model was represented by the equation: $Y_{i j k}=\mu+\mathrm{Ti}+$ Time $\mathrm{j}+\mathrm{Ti} \times$ Time $\mathrm{j}+\varepsilon \mathrm{ijk}$, where Yijk = observation of the effect of treatment $i$, at opening time $j$ and in repetition $\mathrm{k} ; \mu=$ overall mean; $\mathrm{Ti}=$ treatment effect $\mathrm{i}$ applied to plot, with $\mathrm{i}=1,2,3,4$, and 5 ; Time $=$ effect of time after opening; $\mathrm{Ti} \mathrm{x}$ Time $\mathbf{j}=$ interaction between treatments $\mathrm{i}$ and time $\mathrm{j}$ after silo opening; $\varepsilon i \mathrm{jk}=$ random error associated with each observation.

For variables related to ruminal degradation kinetics, the experiment was analyzed in a randomized block design with five treatments, and five replicates. The results were subjected to analysis of variance using the GLM procedure, the means compared by the Scott Knott test at 5\% probability of a type I error.

The mathematical model was represented by equation: $\mathrm{Yij}_{\mathrm{ij}}=\mu+\mathrm{Ti}+\mathrm{Bj}$ $+\varepsilon i j$, where, $Y i j=$ observation of the effect of treatment $\mathrm{i}$, in block j; $\mu=$ overall mean; $\mathrm{Ti}$ = effect of treatment $\mathrm{i}$ applied in the plot, with $\mathrm{i}=1,2,3,4$, and $5 ; \mathrm{Bj}=$ effect of block (animal) $\mathrm{j}$ applied in the plot, with $\mathrm{i}=1,2,3,4$, and $5 ; \varepsilon i j$ = random error associated with each observation.

Treatmentswere compared by the Scott Knott test, and the time of exposure subjected to the analysis of orthogonal contrasts, being tested the linear, and quadratic models. For all statistical procedures, $\alpha=0.05$ was used as the tolerable maximum limit for type I error. 


\section{Results and Discussion}

There was no effect of interaction between treatments and time of exposure to air on the values of $\mathrm{pH}(\mathrm{P}=0.20)$ and temperature $(P=0.29)$ of the ensiled mass. The silage of BRS capiaçu grass combined with pseudostem hay presented $\mathrm{pH}$ value (5.98) 19.23\% higher than the other treatments (mean of 4.83; Table 2). The BRS capiaçu grass silage combined with leaf hay showed a temperature $1.90 \%$ higher than the control silage (without additive). Four days after opening the silo, the BRS capiaçu grass silage showed an increase of $11.34 \%$ in $\mathrm{pH}$, and $7.86 \%$ in temperature.

\section{Table 2}

Values of $\mathrm{pH}$ and temperature $\left({ }^{\circ} \mathrm{C}\right)$ of the BRS capiaçu grass silage combined with different hays of banana crop residue after four days of exposure to air.

\begin{tabular}{|c|c|c|c|c|c|c|}
\hline \multirow{2}{*}{ Item } & \multicolumn{2}{|c|}{$\mathrm{pH}$} & \multicolumn{3}{|c|}{ Temperature $\left({ }^{\circ} \mathrm{C}\right)$} & \multirow{2}{*}{ Mean } \\
\hline & $1^{\circ}$ & $4^{\circ}$ & Mean & 10 & $4^{\circ}$ & \\
\hline Control & 4.52 & 4.84 & $4.68 \mathrm{~B}$ & 25.06 & 27.42 & $26.24 \mathrm{C}$ \\
\hline Banana peel & 4.45 & 5.10 & $4.77 \mathrm{~B}$ & 25.44 & 27.58 & $26.50 \mathrm{~B}$ \\
\hline Pseudostem & 5.55 & 6.42 & $5.98 \mathrm{~A}$ & 25.38 & 27.66 & $26.52 \mathrm{~B}$ \\
\hline Leaf & 4.62 & 5.46 & $5.04 \mathrm{~B}$ & 25.78 & 27.74 & $26.75 \mathrm{~A}$ \\
\hline Mean & $4.61 b$ & $5.2 \mathrm{a}$ & & $25.42 b$ & $27.59 a$ & \\
\hline SEM & \multicolumn{2}{|c|}{0.11} & \multicolumn{3}{|c|}{0.095} & \\
\hline Treatments & \multicolumn{2}{|c|}{$<0.01$} & \multicolumn{3}{|c|}{$<0.01$} & \\
\hline Time & \multicolumn{2}{|c|}{$<0.01$} & \multicolumn{3}{|c|}{$<0.01$} & \\
\hline Treatments*Time & \multicolumn{2}{|c|}{0.20} & \multicolumn{3}{|c|}{0.29} & \\
\hline
\end{tabular}

Control - BRS capiaçu grass silage without additive; Banana peel - BRS capiaçu grass silage $+37.44 \%$ banana peel hay (dry matter basis); Pseudostem - BRS capiaçu grass silage + 36.06\% banana tree pseudostem hay; Leaf - BRS capiaçu grass silage $+37.00 \%$ banana leaf hay. Means followed by different uppercase letters, in the same column, and lowercase letters, in the same row, are significantly different by Scott Knott test $(P<0.05)$. SEM - Standard error of the mean; P - Probability.

According to Muck et al. (2018), the growth of proteolytic microorganisms after silo opening, and yeasts, are factors responsible for the increase in $\mathrm{pH}$ and temperature, which decreases the silage aerobic stability. Four days after opening the silo, the temperature increased $2.17^{\circ} \mathrm{C}$. According to Rezende et al. (2014), the increase in $\mathrm{pH}$ values in silage after opening the silo, as observed in this study, is related to the increase in temperature due to fermentation of silage nutrients with yeasts, and fungi justifying the behavior of the results. The $\mathrm{pH}$ value of the control silage, and silage combined with banana peel hay presented a mean of 4.66 , with a maximum mean of 4.84 and 5.10 verified $96 \mathrm{~h}$ after silo opening, respectively (Table 3). 
Table 3

Values of pH of BRS capiaçu grass silage combined with different hays of banana crop residue after four days of exposure to air.

\begin{tabular}{|c|c|c|c|c|c|c|}
\hline \multirow{2}{*}{ Item (\% DM) } & \multicolumn{4}{|c|}{ BRS capiaçu grass silage } & \multirow{2}{*}{ SEM } & \multirow{2}{*}{ P-value } \\
\hline & Control & Banana peel & Pseudostem & Leaf & & \\
\hline Mean pH & $4.60 \mathrm{c}$ & $4.72 c$ & $6.00 \mathrm{a}$ & $5.12 b$ & 0.06 & $<0.01$ \\
\hline Maximum pH & 4.84 & 5.10 & 5.10 & 5.48 & 0.17 & - \\
\hline Hours for maximum $\mathrm{pH}$ & $>96$ & $>98$ & $>99$ & 48 & - & - \\
\hline
\end{tabular}

Control - BRS capiaçu GRASS silage without additive; Banana peel - BRS capiaçu grass silage $+37.44 \%$ banana peel hay (on a dry matter basis); Pseudostem - BRS capiaçu grass silage $+36.06 \%$ banana tree pseudostem hay; Leaf - BRS capiaçu grass silage $+37.00 \%$ banana leaf hay. Means followed by different letters are significantly different $(P<0.05)$ by Scott Knott test. SEM - Standard error of the mean; P - Probability.

However, BRS capiaçu grass silage combined with pseudostem hay presented higher $\mathrm{pH}$ upon silo opening compared to the control silage (4.60), and maximized the value after $99 \mathrm{~h}$ after silo opening. In turn, BRS capiaçu grass silage combined with banana leaf hay reached maximum $\mathrm{pH}$ (5.48) $48 \mathrm{~h}$ after silo opening. As function of the silo opening times, values of $\mathrm{pH}$ increased linearly, and for each one hour of exposure to air, there was an increase of 0.20 units in $\mathrm{pH}$ (Figure 1).

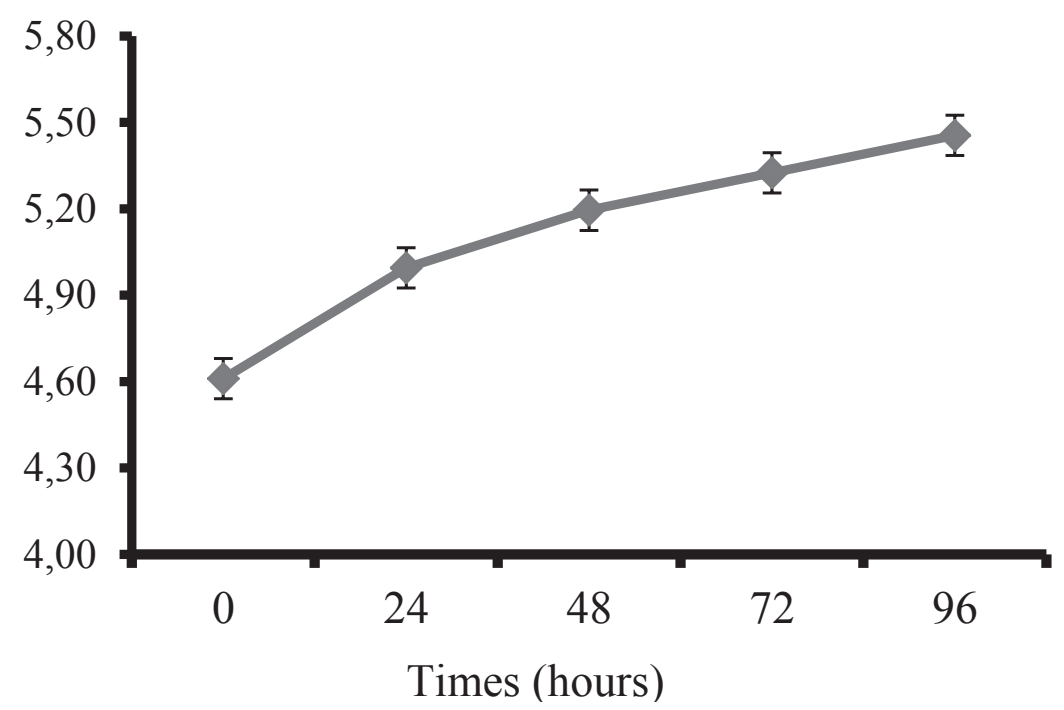

Figure 1. Values of pH of BRS capiaçu grass silage combined with different hays of banana crop residue after silo opening. ( $\left.\hat{\mathrm{Y} p H}=4.51+0.202 * X ; \mathrm{R}^{2}=0.93\right)$ 
For temperature, mean values were fit to a quadratic regression model, and the minimum temperatures were 11.75 , $36.60,36.53$, and $27.94 \mathrm{~h}$ after silo opening, respectively, for control silage, BRS capiaçu silage combined with banana peel hay, BRS capiaçu silage combined with pseudostem hay and BRS capiaçu silage combined with banana leaf hay (Figure 2).

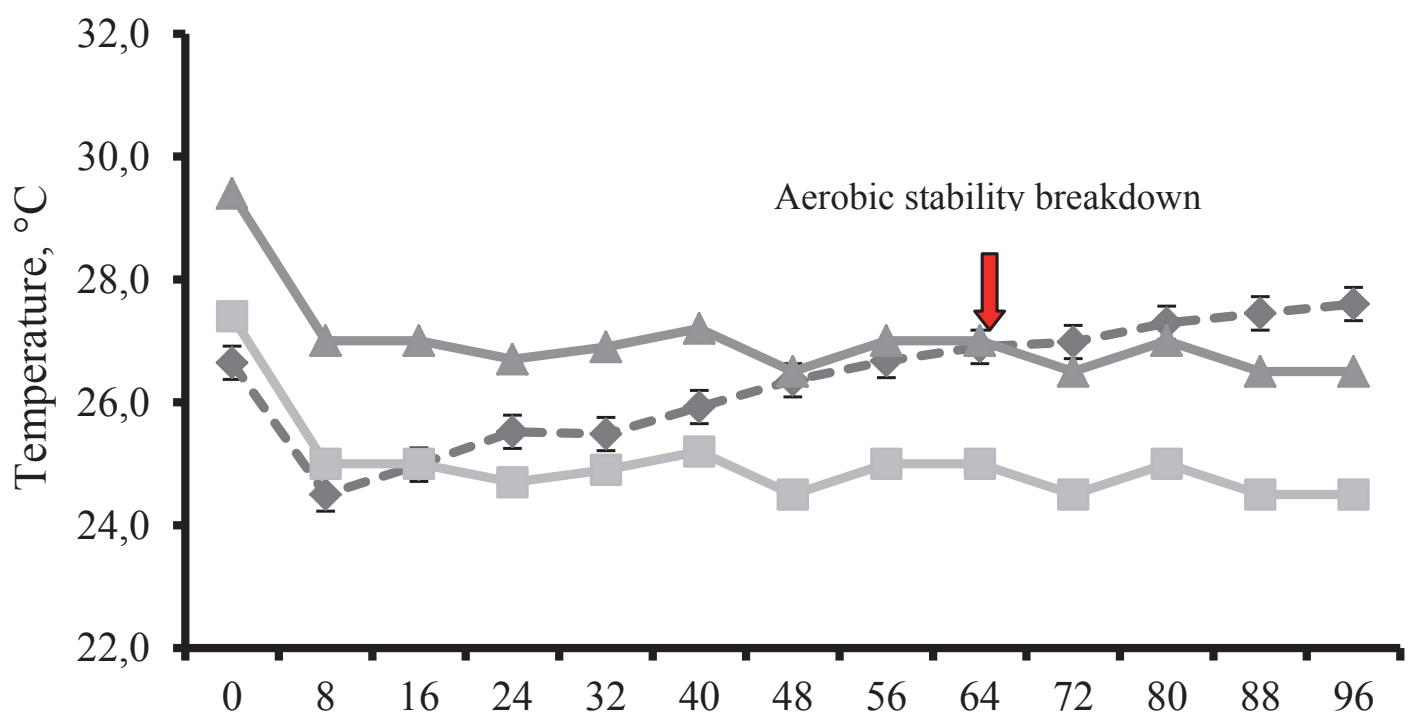

Times (hours)

$\leadsto-$ Treatments $\longrightarrow-$ Temp. Environment $\longrightarrow$ Environment $+2{ }^{\circ} \mathrm{C}$

Figure 2. Aerobic stability breakdown of BRS capiaçu grass silage combined with different hays of banana crop residue after silo opening.

After reaching the minimum temperature values in each treatment, the increase of the same occurred due to the fermentation process, indicating that the environment was favorable to the growth of fungi and yeasts, which consequently affects the nutritional value. This is because the increase in forage temperature in aerobiosis involves the use of organic acids and other soluble nutrients as a source of energy, resulting in nutrient loss (Borreani, Tabacco, Schmidt, Holmes, \& Muck, 2018). However, for all treatments, the aerobic deterioration of silage started from 64 hours of exposure to air, as observed in Figure 2.

There was difference between silages ( $P<0.01$ ) for effluent losses. The BRS capiaçu control silage or combined with pseudostem hay (mean $73.15 \mathrm{~kg} \mathrm{t} \mathrm{GM-1)}$ ) presented effluent losses $40.46 \%$ higher than those observed for BRS capiaçu silage combined with banana leaf hay and $69.17 \%$ in relation to BRS capiaçu silage combined with banana peel (Table 4). 
Table 4

Nutritional value of BRS capiaçu grass silages combined with different hays of banana crop residue.

\begin{tabular}{|c|c|c|c|c|c|c|}
\hline \multirow{2}{*}{ Item (\% DM) } & \multicolumn{4}{|c|}{ BRS capiaçu grass silage } & \multirow{2}{*}{ SEM } & \multirow{2}{*}{ P-value } \\
\hline & Control & Banana peel & Pseudostem & Leaf & & \\
\hline Effluent losses (kg. t GM-1) & $77.67 \mathrm{a}$ & $22.55 c$ & $68.64 a$ & $43.55 b$ & 3.53 & $<0.01$ \\
\hline Gas losses & $3.11 \mathrm{a}$ & $2.63 \mathrm{~b}$ & $2.72 b$ & $2.68 \mathrm{~b}$ & 0.02 & $<0.01$ \\
\hline $\mathrm{N}-\mathrm{NH}_{3}(\% \mathrm{TN})$ & $7.16 \mathrm{~b}$ & $6.17 \mathrm{~b}$ & $3.68 \mathrm{c}$ & $9.20 \mathrm{a}$ & 0.4 & $<0.01$ \\
\hline Dry matter (DM) & $20.18 b$ & $28.89 a$ & $27.03 \mathrm{a}$ & $29.31 \mathrm{a}$ & 1.18 & $<0.01$ \\
\hline Ash & $12.06 \mathrm{~b}$ & $14.84 a$ & $15.82 a$ & $13.81 \mathrm{a}$ & 0.54 & $<0.01$ \\
\hline Ether extract & $2.15 b$ & $3.33 \mathrm{a}$ & $1.74 b$ & $3.71 \mathrm{a}$ & 0.18 & $<0.01$ \\
\hline Crude protein & $7.16 \mathrm{~b}$ & $7.16 \mathrm{~b}$ & $6.05 c$ & $8.37 \mathrm{a}$ & 0.17 & $<0.01$ \\
\hline NDIN, \% CP & $4.05 d$ & $8.52 b$ & $12.89 \mathrm{a}$ & $6.93 c$ & 0.33 & $<0.01$ \\
\hline ADIN, \%CP & $1.17 \mathrm{~d}$ & $6.07 b$ & $8.35 \mathrm{a}$ & $4.58 \mathrm{c}$ & 0.35 & $<0.01$ \\
\hline Neutral detergent fiber & $69.33 \mathrm{a}$ & $62.89 \mathrm{c}$ & $65.88 b$ & $68.75 a$ & 0.79 & $<0.01$ \\
\hline Acid detergent fiber & 47.75 & 46.32 & 49.23 & 46.11 & 1.32 & 0.34 \\
\hline Lignin & 9.43 & 12.66 & 10.76 & 11.4 & 1.14 & 0.29 \\
\hline iNDF & 32.64 & 30.39 & 25.83 & 27.38 & 2.78 & 0.29 \\
\hline Total carbohydrates & $78.61 \mathrm{a}$ & $74.66 \mathrm{~b}$ & $77.95 a$ & $74.09 \mathrm{~b}$ & 0.68 & $<0.01$ \\
\hline Non-fiber carbohydrates & 9.28 a & $11.77 \mathrm{a}$ & $12.06 a$ & $5.33 c$ & 1.15 & $<0.01$ \\
\hline Total digestible nutrients & $42.92 \mathrm{c}$ & $46.36 \mathrm{a}$ & $42.54 \mathrm{c}$ & $44.77 \mathrm{~b}$ & 0.36 & $<0.01$ \\
\hline ME, Mcal kg-1 DM & $1.55 \mathrm{c}$ & $1.67 \mathrm{a}$ & $1.53 \mathrm{c}$ & $1.62 b$ & 0.02 & $<0.01$ \\
\hline DE, Mcal kg-1 DM & $1.89 \mathrm{c}$ & $2.04 \mathrm{a}$ & $1.87 \mathrm{c}$ & $1.97 \mathrm{~b}$ & 0.01 & $<0.01$ \\
\hline In vitro dry matter digestibility & $56.52 b$ & $54.90 b$ & $62.52 a$ & $52.48 \mathrm{c}$ & 1.03 & $<0.01$ \\
\hline $\begin{array}{c}\text { In vitro neutral detergent fiber } \\
\text { digestibility }\end{array}$ & $43.25 b$ & $38.06 \mathrm{c}$ & $51.28 a$ & $38.95 c$ & 1.18 & $<0.01$ \\
\hline
\end{tabular}

GM - Green matter; N-NH3 - Ammonia nitrogen; TN - total nitrogen; DM - dry matter; CP - Crude protein; NDIN - Neutral detergent insoluble nitrogen; ADIN - Acid detergent insoluble nitrogen; iNDF - Indigestible neutral detergent fiber; ME Metabolizable energy; DE - Digestible energy; NDF - Neutral detergent fiber. Control - BRS capiaçu grass silage without additive; Banana peel - BRS capiaçu grass silage $+37.44 \%$ banana peel hay (on a dry matter basis); Pseudostem - BRS capiaçu grass silage $+36.06 \%$ banana tree pseudostem hay; Leaf - BRS capiaçu grass silage $+37.00 \%$ banana leaf hay. Means followed by different letters are significantly different $(P<0.05)$ by Scott Knott test. SEM - Standard error of the mean; P - Probability.

Due to the particle size and density of pseudostem and banana leaf hay, compaction has certainly been compromised, not being sufficient for water holding capacity since the integrity of plant cells was maintained. Poor silage compaction can result in air storage in the mass allowing plant respiration and growth of microorganisms producing water, and contributing to the formation of effluents (Brüning et al., 2017). This was not verified in the other treatments. In elephant grass silage cv. BRS capiaçu, Jesus et al. (2021), Ribas et al. (2021), and Monção et al. (2020b) verified effluent losses of $113.73 \mathrm{~kg}$. t. GM ${ }^{-1}$ (harvested at 90 days), $85.02 \mathrm{~kg}$. t. $\mathrm{GM}^{-1}$ (harvested at 100 days), and $36.27 \mathrm{~kg}$. t. GM ${ }^{-1}$ (harvested at 
150 days), respectively. In the present study, the mean value was $77.67 \mathrm{~kg}$. t. $\mathrm{GM}^{-1}$ for BRS capiaçu control silage, and $22.55 \mathrm{~kg}$. t. $\mathrm{GM}^{-1}$ for BRS capiaçu grass silage combined with banana peel hay. According to the authors, effluent losses are influenced by the dry matter content of the ensiled crop, silo type, degree of compaction, and the physical processing of the forage.

The inclusion of banana crop residue (hay) when ensiling BRS capiaçu grass decreased $13.93 \%$ gas losses compared to the control silage (mean 3.11\% DM). According to Bolsen (2018), after 15-20 days of ensiled mass, numerous gases are produced inside the silo during fermentation as carbon dioxide and nitric oxide that can cause intoxication in humans and animals housed near the silos.

Ammonia nitrogen $\left(\mathrm{N}-\mathrm{NH}_{3}\right)$ content was $60 \%$ higher in BRS capiaçu grass silage combined with leaf hay compared to BRS capiaçu silage combined with pseudostem hay, and $27.60 \%$ higher than BRS capiaçu control silage and BRS capiaçu silage combined with banana peel hay (mean $6.66 \%$ total nitrogen). The inclusion of banana crop residue (hay) in ensiling BRS capiaçu grass increased 28.96 percentage units dry matter content (DM) compared to the control silage $(20.18 \%$; $P$ $<0.01$ ). This was due to the high DM content of the additives used to absorb moisture from the mass (Table 1). Kung, Shaver, Grant, \& Schmidt, (2018) observed that DM content of grass silage should range from 25 to $35 \%$ for adequate fermentation, which highlights the importance of additives in increasing DM content. However, it is possible to observe adequate fermentation in BRS capiaçu grass with more than 20\% DM (Jesus et al., 2021; Ribas et al., 2021).
The inclusion of banana crop residue (hay) in ensiling BRS capiaçu grass increased $18.62 \%$ ash content compared to the control silage (mean 12.06\%), which is due to the chemical composition of the residue (Table 1). The protein content in BRS capiaçu silage combined with leaf hay was $14.45 \%$ higher than the mean $(7.16 \%)$ of the control silage and BRS capiaçu silage combined with banana peel hay. Elephant grass silage combined with pseudostem hay present lower crude protein content (6.05\%), being $12.89 \%$ and 8.35 percentage units neutral detergent insoluble nitrogen $(P<0.01)$, and acid detergent insoluble nitrogen $(P<0.01)$, respectively.

There was no difference in ether extract content between grass silage with banana peel hay and grass silage with leaf hay (mean 3.52\%; $P>0.05$ ). The inclusion of banana peel hay and pseudostem hay in the elephant grass silage reduced neutral detergent fiber (NDF; P <0.01) compared to the other silages. There was no difference between the control silage and BRS capiaçu silage combined with pseudostem hay on total digestible nutrient contents (TDN; mean 42.73\%). There was no difference between silages on ADF and lignin values (means of $47.35 \%$, and $11.06 \%)$, respectively. However, higher TDN, metabolizable energy and, digestible energy content was verified in BRS capiaçu silage combined with banana peel. The greater in vitro dry matter digestibility, and in vitro NDF digestibility was verified in BRS capiaçu silage combined with pseudostem hay. There was difference between silages $(P<0.01)$ for the readily soluble fraction of DM (Fraction a; Table 5). The greater presence of soluble crude protein justifies the higher fraction "a" in BRS capiaçu silage combined with banana peel hay, and leaf hay. 


\section{Table 5}

Ruminal degradation parameters of the dry matter of BRS capiaçu grass silages combined with different hays of banana crop residue.

\begin{tabular}{|c|c|c|c|c|c|c|}
\hline \multirow{2}{*}{ Item, \% } & \multicolumn{4}{|c|}{ BRS capiaçu grass silage } & \multirow{2}{*}{ SEM } & \multirow{2}{*}{ P-value } \\
\hline & Control & Banana peel & Pseudostem & Leaf & & \\
\hline Fraction a & $12.57 b$ & $15.22 \mathrm{a}$ & $13.72 b$ & 15.60 a & 0.39 & $<0.01$ \\
\hline Fraction b & $52.51 \mathrm{~b}$ & $45.91 \mathrm{c}$ & $56.71 \mathrm{a}$ & $39.04 \mathrm{~d}$ & 0.87 & $<0.01$ \\
\hline$c, \% h^{-1}$ & $4.75 a$ & $3.75 b$ & $3.25 b$ & $3.75 b$ & 0.01 & 0.01 \\
\hline Colonization time, $\mathrm{h}$ & $5.44 b$ & $5.43 b$ & $7.36 a$ & $5.15 b$ & 0.39 & 0.01 \\
\hline Potential degradability & $65.08 \mathrm{~b}$ & $61.14 \mathrm{c}$ & 70.43 a & $54.65 d$ & 1.17 & $<0.01$ \\
\hline Effective degradability, $2 \% \mathrm{~h}^{-1}$ & $47.86 \mathrm{a}$ & $45.19 b$ & $47.65 \mathrm{a}$ & $41.13 c$ & 0.14 & $<0.01$ \\
\hline Effective degradability, $5 \% \mathrm{~h}^{-1}$ & $36.62 \mathrm{a}$ & $34.94 b$ & $34.95 b$ & $32.43 \mathrm{c}$ & 0.28 & $<0.01$ \\
\hline Effective degradability, $8 \% \mathrm{~h}^{-1}$ & $30.89 a$ & $29.92 b$ & $29.18 \mathrm{c}$ & $28.16 d$ & 0.28 & $<0.01$ \\
\hline Undegradable fraction & $34.91 \mathrm{c}$ & $38.86 \mathrm{~b}$ & $29.56 \mathrm{~d}$ & $45.35 \mathrm{a}$ & 1.44 & $<0.01$ \\
\hline
\end{tabular}

c- Degradation rate of fraction Bp "c". Control - BRS capiaçu silage without additive; Banana peel - BRS capiaçu grass silage $+37.44 \%$ banana peel hay (on a dry matter basis); Pseudostem - BRS capiaçu grass silage $+36.06 \%$ banana tree pseudostem hay; Leaf - BRS capiaçu grass silage $+37.00 \%$ banana leaf hay. Means followed by different letters are significantly different $(P<0.05)$ by Scott Knott test. SEM - Standard error of the mean; P - Probability.

The highest mean of fraction "b", and potential degradability were found in BRS capiaçu grass silage combined with pseudostem hay. In general, the greater in vitro digestibility of DM, NDF and the potential degradability of DM in BRS capiaçu silage combined with pseudostem hay are justified by the structural arrangement of pseudostem fibers that favors the action of ruminal microorganisms (Rabelo et al., 2020; Rigueira et al., 2020). Furthermore, it is possible to verify a higher fraction Bp in BRS grass capiaçu silage combined with pseudostem hay compared to the other silages.

The colonization time of ruminal microorganisms on the substrates varied between the treatments $(P<0.05)$, being the longest time found in silage with banana pseudostem hay (7.36 h). According to Jesus et al. (2021), the colonization time corresponds to the interval between the beginning of the incubation until the lag time, being influenced by the diet, as greater presence of fermentable carbohydrates, and by physical and chemical characteristics of the cell wall. Furthermore, the particle size and the low crude protein content $(60.5 \mathrm{~g} / \mathrm{kg}$ DM) may be contributing to higher TC verified in BRS capiaçu silage combined with pseudostem hay. According to Van Soest (1994), availability of nitrogen to ruminal bacteria, especially fibrolytic bacteria, is fundamental to the onset of substrate fermentation.

The BRS capiaçu grass silage combined with leaf hay presented value of undegradable fraction (UF) $18.66 \%$, and $34.81 \%$ higher than the mean of the control silage, and BRS capiaçu grass silage combined with pseudostem hay, respectively. Usually, only the high lignin content estimated in DM justifies the lower potential for degradation of the substrate in the rumen, as observed in BRS capiaçu 
grass silage combined with leaf hay, $164.2 \mathrm{~g}$ $\mathrm{kg}^{-1}$ (Rabelo et al., 2020). Lignin is a phenolic compound that has mainly $p$-coumaric and ferulic acids whose presence in the ruminal environment is causes the intoxication of microorganisms (Van Soest, 1994). Another form of lignin in reducing the PD of DM is the structural arrangement and ester-type bonds formed with hemicellulose and the presence of tannins (Van Soest, 1994).
This behavior is clear when the ruminal kinetics of NDF is analyzed (Table 6), where BRS capiaçu grass silage combined with leaf hay and BRS capiaçu grass silage combined with banana peel hay showed potential degradability (Fraction Bp) of NDF (mean of $47.28 \%$ ). This is because both leaf and banana peel hay may contain condensed tannins (7.8\% from DM), whose rumen action inhibits microbial access to the substrate (Rigueira et al., 2021).

\section{Table 6}

Ruminal degradation parameters of the neutral detergent fiber of BRS grass capiaçu silages combined with different hays of banana crop residue.

\begin{tabular}{|ccccccc}
\multirow{2}{*}{ Item, \% } & \multicolumn{3}{c}{ BRS capiaçu grass silage } & SEM & P-value \\
\cline { 2 - 5 } Fraction Bp & Control & Banana peel & Pseudostem & Leaf & & \\
c, \% h-1 & $61.64 \mathrm{~b}$ & $49.58 \mathrm{c}$ & $64.13 \mathrm{a}$ & $44.98 \mathrm{c}$ & 1.83 & $<0.01$ \\
Effective degradability, 2\% $\mathrm{h}^{-1}$ & $2.00 \mathrm{~b}$ & $3.00 \mathrm{a}$ & $2.25 \mathrm{~b}$ & $3.00 \mathrm{a}$ & 0.01 & 0.01 \\
Effective degradability, $5 \% \mathrm{~h}^{-1}$ & $17.98 \mathrm{~b}$ & $29.06 \mathrm{c}$ & $35.15 \mathrm{a}$ & $27.52 \mathrm{~d}$ & 0.43 & $<0.01$ \\
Effective degradability, 8\% $\mathrm{h}^{-1}$ & $12.76 \mathrm{~b}$ & $13.32 \mathrm{~b}$ & $21.01 \mathrm{a}$ & $17.41 \mathrm{~b}$ & 0.49 & $<0.01$ \\
Ip & $38.36 \mathrm{~b}$ & $50.42 \mathrm{a}$ & $35.86 \mathrm{~b}$ & $55.02 \mathrm{a}$ & 1.83 & $<0.01$ \\
\hline
\end{tabular}

c - Degradation rate of the fraction Bp "c"; Ip - standardized undegradable fraction; k - Rate of passage suggested by AFRC (1993). Control - BRS capiaçu grass silage without additive; Banana peel - BRS grass capiaçu silage $+37.44 \%$ banana peel hay (on a dry matter basis); Pseudostem - BRS capiaçu grass silage $+36.06 \%$ banana tree pseudostem hay; Leaf - BRS capiaçu grass silage $+37.00 \%$ banana leaf hay. Means followed by different letters are significantly different $(\mathrm{P}<0.05)$ by Scott Knott test. SEM - Standard error of the mean; P - Probability.

BRS capiaçu grass silage combined with pseudostem hay showed greater effective degradability of the fiber fraction at all rates of passage $(2,5$ and $8 \% / h)$ compared to the other silages. This is justified by the longer time of microbial colonization, fraction b of DM, and fraction Bp. In general, the inclusion of hay of banana crop residue in ensiling BRS capiaçu grass reduced gas losses despite the fact that pseudostem hay did not decrease effluents losses compared to the control silage. Another important point is that the silage with additives had a higher DM content. Despite having better crude protein content in BRS capiaçu grass silage combined with leaf hay and TDN in BRS capiaçu grass silage combined with banana peel and leaf hay compared to the control silage, these silages showed less digestibility and ruminal degradability of DM and NDF. Unlike BRS capiaçu grass silage combined with pseudostem hay, which showed greater digestibility and ruminal degradability of DM and NDF. 


\section{Conclusion}

The inclusion of $37.44 \%$ banana peel hay improves the fermentation profile and aerobic stability of BRS capiaçu grass silage. Regarding nutritional value, the inclusion of $36.06 \%$ banana pseudostem hay results in better values of ruminal degradability and digestibility of BRS capiaçu grass silage.

\section{Acknowledgements}

The authors are grateful to the Research Support Foundation of the State of Minas Gerais (FAPEMIG); Unimontes; National Institute of Science and Technology (INCT); Embrapa Gado de Leite and the National Council for Scientific and Technological Development (CNPq). This study was partially funded by the Coordination for the Improvement of Higher Education Personnel - Brazil (CAPES) - Financial Code 001. The authors would like to thank the undergraduate students for their contribution towards the accomplishment of the research.

\section{References}

Agricultural and Food Research Council (1993). Energy and protein requirements of ruminants. Walligford: CAB International.

Bolsen, K. K. (2018). Silage review: safety considerations during silage making and feeding. Journal of Dairy Science, 101(5), 4122-4131. doi: 10.3168/jds.2017-13738

Borreani, G., Tabacco, E., Schmidt, R. J., Holmes, B. J., \& Muck, R. E. (2018).Silage review: factors affecting dry matter and quality losses in silages. Journal of Dairy Science, 101(1), 3952-3979. doi: 10. 3168/jds.2017-13837
Brant, L. M. S., Pimentel, P. R. S., Rigueira, J. P. S., Alves, D. D., Carvalho, M. A. M., \& Alves, W. S. (2017). Fermentative characteristics and nutritional value of elephant grass silage added with dehydrated banana peel. Acta Scientiarum. Animal Sciences, 39(2), 123-129. doi: 10.4025/actascianimsci. v39i2.33925

Brüning, D., Gerlach, K., Weiß, K., \& Südekum, K.-H. (2017). Effect of compaction, delayed sealing and aerobic exposure on maize silage quality and on formation of volatile organic compounds. Grass and Forage Science, 73(1), 53-66. doi: $10.1111 / \mathrm{gfs} .12288$

Detmann, E., Souza, M. A., Valadares, S. C., F'., Queiroz, A. C., Berchielli, T. T., Saliba, E. O. S.,... Azevedo, J. A. G. (2012). Métodos para análise de alimentos. Visconde do Rio Branco, MG: Suprema.

Goes, R. H. T. B., Patussi, R. A., Gandra, J. R., Branco, A. F., Cardoso, T. J. L., Oliveira, M. V. M.,... Souza, C. J. S. (2017). The crambe (Crambe abyssinica Hochst) byproducts, can be used as a source of non-degradable protein in the rumen? Bioscience Journal, 33(1), 113-120. doi: 10.14393/BJ-v33n1a2017-33105

Jesus, M. A., Monção, F. P., Rigueira, J. P. S., Rocha, V. R., Jr., Gomes, V. M., Delvaux, N. A., Jr.,... Santos, A. S. (2021). Effects of microbial inoculant and fibrolytic enzymes on fermentation quality and nutritional value of BRS capiaçu grass silage. Semina: Ciências Agrárias, 42(3), 1-13. doi: 10.5433/16 79-0359.2021v42n3Supl1p1837

Jobim, C. C., Nussio, L. G., Reis, R. A., \& Schmidt, P. (2007). Avanços metodológicos na avaliação da qualidade de forragem 
conservada. Revista Brasileira de Zootecnia, 36(1), 101-119. doi: 10.1590/ S1516-35982007001000013

Kung, L., Jr., Shaver, R. D., Grant, R. J., \& Schmidt, R. J. (2018). Silage review: interpretation of chemical, microbial, and organoleptic components of silages. Journal of Dairy Science, 101(1), 4020-4033. doi: 10.3168/ jds.2017-13909

Mertens, D. R., \& Loften, J. R. (1980). The effects of starch on forage fiber digestion kinetics in vitro. Journal of Dairy Science, 63(9), 1437-1446. doi: 10.3168/jds.SOO 22-0302(80)83101-8

Monção, F. P., Costa, M. A. M. S., Rigueira, J. P. S., Moura, M. M. A., Rocha, V. R., Jr., Mesquita, V. G.,... Chamone, J. M. A. (2019). Yield and nutritional value of BRS Capiaçu grass at different regrowth ages. Semina: Ciências Agrárias, 41(5), 745-755. doi 10.5433/1679-0359.2019v40n5p2045

Monção, F. P., Costa, M. A. M. S., Rigueira, J. P. S., Sales, E. C. J., Leal, D. B., Silva, M. F. P.,... Rocha, V. R., Jr. (2020a). Productivity and nutritional value of BRS capiaçu grass (Pennisetum purpureum) managed at four regrowth ages in a semiarid region. Tropical Animal Health and Production, 52(1), 235-241. doi: 10.1007/s11250019-02012-y

Monção, F. P., Rocha, V. R., Jr., Silva, J. T., Jesus, N. G., Marques, O. F. C., Rigueira, J. P. S.,... Leal, D. B. (2020b). Nutritional value of BRS capiaçu grass (Pennisetum purpureum) silage associated with cactus pear. Iranian Journal of Applied Animal Science, 10(1), 25-29. Retrieved from http://ijas.iaurasht. ac.ir/ article 671563.html
Muck, R. E., Nadeau, M. G., McAllister, T. A., Contreras-Govea, F. E., Santos, M. C., \& Kung, L., Jr. (2018). Silage review: recent advances and future uses of silage additives. Journal of Dairy Science, 101(5), 3980-4000. doi: 10.3168/jds.2017-13839

National Research Council (2001). Nutrient requirements of dairy cattle (7nd rev. ed.). Washington, DC: National Academy Press.

Noel, R. J. \& Hambleton, L. G. (1976). Collaborative study of a semiautomated method for determination of crude protein in animal feeds. Journal of the AOAC, 59(1)134-140.

Ørskov, E. R., \& Mcdonald, I. (1979). The estimation of degradability in the rumen form incubation measurement weighted according to rate of passage. Journal of Agricultural Science, 92(2), 499-508. doi: $10.1017 /$ S0021859600063048

Paula, P. R. P., Neiva, A. P., Jr., Souza, W. L., Abreu, M. J. I., Teixeira, R. M. A., Cappelle, E. R., \& Tavares, V. B. (2020). Composição bromatológica da silagem de capimelefante BRS capiaçu com inclusão fubá de milho. PUBVET, 14(10), 1-11. doi: 10.31533/pubvet.v14n10a682.1-11

Pereira, A. V., Lédo, F. J. S., \& Machado, J. C. (2017). BRS Kurumi and BRS capiaçu new elephant grass cultivars for grazing and cut-and-carry system. Crop Breeding and Applied Biotechnology, 17(1), 59-62. doi: 10.1590/1984-70332017v17n1c9

Rabelo, W. O., Rocha, V. R., Jr., Monção, F. P., Costa, N. M., Rigueira, J. P. S., Souza, B. P.,... Pires, D. A. A. (2020). Effect of different roughage sources associated banana pseudostem hay on the nutritional and 
behavioral parameters and performance of F1 Holstein/Zebu lactation cows. Tropical Animal Health and Production, 52(6), 3769-3780. doi: 10.1007/s11250020-02414-3

Rezende, A. V., Rabelo, C. H. S., Veiga, R. M., Andrade, L. P., Härter, C. J., Rabelo, F. H. S.,... Reis, R. A. (2014). Rehydration of corn grain with acid whey improves the silage quality. Animal Feed Science and Technology, 197(1), 213-221. doi: 10.1016/j.anifeedsci.2014.07.009

Ribas, W. F. G., Monção, F. P., Rocha, V. R., Jr., Maranhão, C. M. A., Ferreira, H. C., Santos, A. S.,... Rigueira, J. P. S. (2021). Effect of wilting time and enzymatic-bacterial inoculant on the fermentative profile, aerobic stability, and nutritional value of BRS capiaçu grass silage. Revista Brasileira de Zootecnia, 50(1), 1-12. doi: 10.37496/rbz5020200207

Rigueira, J. P. S., Jesus, N. G., Rocha, V. R., Jr., Monção, F. P., Costa, N. M., David, G. S. S.,... Carvalho, C. C. S. (2021). Effects of different banana crop wastes on nutrient intake and digestibility, microbial protein synthesis, feeding behavior, and animal performance of $3 / 4$ Holstein $\times$ Zebu heifers in a semiarid rangeland. Tropical Animal Health and Production, 53(1), 1-13. doi: 10.1007/s11250-021-02660-z

Rigueira, J. P. S., Jesus, N. G., Sales, E. C. J., Rocha, V. R., Jr., Santos, A. S., Silva, F. V.,... Monção, F. P. (2020). Nutritional value of pre-dried banana tree pseudostem ammoniated with protected urea. Semina: Ciências Agrárias, 41(4), 1345-1354. doi: 10.5433/1679-0359.2020v41n4p1345
Silva, M. C. A., Costa, N. M., Rigueira, J. P. S., Jesus, D. L. S., Silva, N. B. S., Silva, W. S., Fo.,... Monção, F. P. (2019). The effect of graded levels of crude glycerin in BRS capiaçu grass silage: fermentation profile and bromatological composition. Iranian Journal of Applied Animal Science, 9(4), 597-602. Retrieved from http://www. iaujournals.ir/article_669299.html

Statistical Analysis System Institute (2008). SAS/STAT 9.2 user's guide. Cary, NC: SAS Institute, Inc.

Tilley, J. M. A., \& Terry, R. A. (1963). A twostage technique for the in vitro digestion of forage crops. Journal of the British Grassland Society, 18(2), 104-111. doi: 10.1111/j.1365-2494.1963.tb00335.x

Valente, T. N. P., Detmann, E., Queiroz, A. C., Valadares, S. C., F., Gomes, D. I., \& Filgueiras, J. F. (2011). Evaluation of rumen degradation profiles of forages using bags made from different textiles. Revista Brasileira de Zootecnia, 40(11), 2565-2573. doi: 10.1590/S1516-359820 11001100039

Van Soest, P. J. (1994). Nutritional Ecology of the Ruminant. (2nd ed.). Cornell University Press: New York. 
